\title{
Services for patients with dementia
}

\author{
David Jolley
}

"Start with a careful look at the long-stay wards. If good things are happening there, the rest of the service is almost certainly okay."

Useful advice from an experienced campaigner in the quest to improve services for the elderly, including the elderly mentally ill (Professor Woodford Williams). What, then, do we make of services that offer no long-term care? The Alzheimer's Disease Society (ADS) in two important reports published during 1993 have put their finger where the pain is greatest. Families, carers, patients and professionals despair where services fail to provide a final safe haven for the most damaged, most difficult, most disturbed patients when all else has been tried and tested and found wanting, usually effort and invention sustained for years. Age Concern has drawn attention to the same issue (1990) with similar conclusions.

At a conference sponsored by the Department of Health, ADS, Age Concern, The Royal College of Psychiatrists, The Royal College of General Practitioners, and Association of Directors of Public Health Medicine (Dementia Concern, 1993), it was recognised that the good things being done - to bring patients with dementia early into contact with specialists for assessment, investigation and treatment, to organise enlightened support and monitoring for patients and carers at home - are often threatened by a dark cloud of anxiety and doubt. When matters become really difficult, adequate and appropriate resource is not reliably available. Financial considerations rather than regard for the best clinical management of the situation are seen to be pre-eminent in some parts of the country. Some health authorities have opted to provide very little or no hospice-type, long-term care within the main framework of NHS hospitals. This shifts the responsibility for such care to families, social services, and the 'independent' sector, denying the 'health' component of the problem at a time when the ravages of the illness (Alzheimer's disease, other dementias or other disorders) are at their greatest and death may be not far away (Black \& Jolley, 1990). The responsibilities in question are primarily for skilled, informed and trusted caring and treatment, but along with these goes a financial consequence. The abandonment of national norms, applauded by some as another much needed reduction of red tape, has led to a deregulation of health care - and exposure of the most vulnerable of patients to competition for resource with others. The most vulnerable have lost out. NHS monies are being redirected to more fashionable activities.

This is a shameful situation and we must be grateful to the ADS and Age Concern for bringing the scandal to public attention. Standards are demanded more often now than at any previous time and this is an area where standards must be reintroduced. There is evidence suggesting that a reasonable ration of long-term NHS beds increases the likelihood that patients are sustained at home (rather than money going into residential or nursing home care) (Benbow \& Jolley, 1994).

At the heart of every psychogeriatric service there should be appropriately sited continuing care beds, linked to day hospitals and to community services. These provide not only high quality care for the relatively few patients in need of this special resource, but also training, education and support to others involved with patients whose problems are similar if not (yet) so severe (Royal College of Psychiatrists, 1993; Jolley \& Arie, 1991).

\section{References}

AGE CONCERN (1990) Under Sentence - Continuing care units for older people within the NHS. London: Age Concern. ALZHEIMER'S DISEASE SOCIETY (1993) Deprtuation and Dementia. London: Alzheimer's Disease Society.

- (1993) NHS Continuing Care Beds. London: Alzheimer's Disease Society.

BENBOW, S.M. \& JOLLEY, D. Provision of residential care for vulnerable old people. Journal of Mental Health (in press). BLACK. D. \& JOLLEY. D. (1990) Deaths in psychiatric care. International Journal of Gerlatric Psychiatry. 6, 489-495. Dementia Concern (1993) Conference at Regent's Park College: ADS. Age Concern. The Royal College of Psychiatrists. The Royal College of General Practitioners. Association of Directors of Public Health. November 1993. JOLLY, D. \& ARIE, T. (1991) Developments in psychogeriatric services. Chapter 11, 117-135. In Recent Advances in Psychogeriatric Medicine 2.

ROYAL COLLEGE OF PSYCHIATRISTs (1993) Mental Health of the Nation. London: Royal College of Psychiatrists.

David Jolley, Consultant Psychiatrist/Reader, University Hospital of South Manchester and Chairman, Old Age Section, The Royal College of Psychiatrists 